\title{
JURNALKU
}

Volume 1 No. 4, Desember 2021

\section{APAKAH LAPORAN KEUANGAN KOPERASI X TELAH SESUAI DENGAN SAK ETAP?}

\author{
Defina Karunia Putri ${ }^{1)}$, Arifah Fibri Andriani2) \\ 1) definaputri11@gmail.com), Program D3 Akuntansi Politeknik Keuangan Negara STAN \\ ${ }^{2)}$ arifahfibri@pknstan.ac.id, Program D3 Akuntansi Politeknik Keuangan Negara STAN* \\ *email korespondensi
}

\begin{abstract}
This study aims to review the implementation of financial accounting standards in the financial statements of Koperasi Pegawai Republik Indonesia X, located in Tegal. The research method employs a content analysis approach sourced from the entity's financial statements. The research data is financial statements of 2019, obtained directly from the entity's management. SAK ETAP and Permen KUMK No. 13 of 2015 are employed as a reference in conducting further analysis based on data and information that has been obtained from content analysis. This study concludes that, in general, KPRI X has presented financial reports under SAK ETAP and Permen KUMK No. 13 of 2015. This study also recommends the Indonesian Accounting Association and the Ministry of Cooperatives and Small and Medium Enterprises to coordinate financial accounting standards for cooperatives in Indonesia.
\end{abstract}

Keywords: Implementation, Cooperatives, Financial Accounting Standards

\begin{abstract}
Abstrak
Tujuan penelitian ini adalah mengulas penerapan standar akuntansi keuangan dalam laporan keuangan Koperasi Pegawai Republik Indonesia X yang berlokasi di Kota Tegal. Metode penelitian dilakukan dengan menggunakan pendekatan analisis konten yang bersumber dari laporan keuangan entitas. Data penelitian berupa laporan keuangan tahun 2019 yang diperoleh langsung dari pengurus entitas. SAK ETAP dan Permen KUMK No. 13 Tahun 2015 digunakan sebagai rujukan dalam melakukan analisis lebih lanjut berdasarkan data dan informasi yang telah diperoleh dari analisis konten. Penelitian ini menyimpulkan bahwa secara umum KPRI X telah menyajikan laporan keuangan sesuai dengan SAK ETAP maupun Permen KUMK No. 13 Tahun 2015. Penelitian ini juga menyarankan kepada Ikatan Akuntansi Indonesia dan Kementerian Koperasi dan Usaha Kecil dan Menengah untuk melakukan koordinasi dalam penyusunan standar akuntansi keuangan untuk koperasi di Indonesia.
\end{abstract}

Kata Kunci: Implementasi, Koperasi, Standar Akuntansi Keuangan

\section{PENDAHULUAN}

Koperasi merupakan sebuah entitas yang sangat penting dalam struktur perekonomian Indonesia (Kader, 2018). Berbeda dari badan usaha lainnya, koperasi didirikan atas dasar usaha bersama sebagai gerakan ekonomi rakyat yang berlandaskan asas kekeluargaan (Republik Indonesia, 1992). Koperasi dibentuk untuk memenuhi tujuan bersama para anggotanya maupun masyarakat pada umumnya. UUD 1945 pasal 33 ayat (1) menyatakan bahwa koperasi merupakan saka guru perekonomian nasional Indonesia. Peran pemerintah dalam mendukung dan memajukan koperasi sangatlah penting. Hal ini bertujuan untuk mewujudkan koperasi yang profesional. Dalam mengembangkan usahanya, koperasi harus menerapkan prinsipprinsip koperasi yaitu transparansi, keterbukaan, dan akuntabilitas.

Perkembangan koperasi di Indonesia cukup signifikan di antara derasnya arus perekonomian global. Jumlah koperasi aktif di Indonesia mencapai 127.124 unit dengan jumlah total aset mencapai Rp221,99 Triliun, volume usaha Rp174,03Triliun dan Sisa Hasil Usaha Rp7,22 triliun per posisi 31 Desember 2020 (Rizaty, 2021). Koperasi mempunyai kontribusi terhadap PDB nasional yang terus meningkat yaitu 4,48\% pada tahun 2017, naik menjadi 5,1\% pada tahun 2019 (Kementerian Koperasi dan Usaha Kecil dan Menengah, 2020). Perkembangan koperasi diharapkan memiliki peran dalam perekonomian nasional, sehingga koperasi dituntut untuk mampu bersaing dan berkembang dengan baik (Kementerian Koperasi dan Usaha Kecil dan Menengah, 2020). 


\section{JURNALKU}

Volume 1 No. 4, Desember 2021

Penyusunan laporan keuangan untuk koperasi biasanya masih belum disajikan sesuai dengan standar akuntansi keuangan (Fatmawati \& Maulana, 2021; Handayani et al., 2017; Indawatika, 2017; Karsimin, 2021; Laliwu et al., 2021; Simatupang, 2018; Yuniarsih, 2016). Laporan keuangan menyajikan informasi yang menyangkut kondisi, kinerja dan perubahan posisi keuangan koperasi, sehingga laporan keuangan koperasi harus disusun sesuai dengan standar akuntansi keuangan yang berlaku. Laporan keuangan dapat digunakan sebagai analisis pengembangan bisnis oleh perusahaan, maupun digunakan pengambilan keputusan oleh investor dan kreditor (Kieso et al., 2018). Dengan demikian, penelitian terkait dengan penyusunan laporan keuangan koperasi perlu untuk dilakukan kembali dengan objek yang berbeda.

Penelitian ini bertujuan untuk mengulas implementasi standar akuntansi entitas tanpa akuntabilitas publik pada laporan keuangan KPRI X. Penelitian ini berbeda dengan penelitian sebelumnya karena penelitian ini mengulas laporan keuangan KPRI berdasarkan SAK ETAP dan Peraturan Menteri Koperasi dan Usaha Kecil Menengah No 13 Tahun 2013 tentang Pedoman Umum Akuntansi Simpan Pinjam yang mana penyusunan pedoman ini juga didasarkan pada SAK ETAP. SAK ETAP tidak menyebutkan secara rinci komponen laporan keuangan koperasi simpan pinjam. KPRI X berlokasi di Kota Tegal yang beranggotakan para pegawai negeri sipil khususnya yang bekerja di Kota Tegal. Kegiatan usaha utama KPRI X melakukan simpan pinjam khusus untuk anggota koperasi dan menyediakan barang dan jasa untuk anggota maupun non anggota koperasi.

\section{KAJIAN PUSTAKA}

Peraturan Menteri Koperasi dan Usaha Kecil dan Menengah (Permen KUKM) Nomor 13 Tahun 2015 tentang pedoman akuntansi usaha simpan pinjam oleh koperasi menjadi panduan dalam penyusunan laporan keuangan koperasi simpan pinjam (Menteri Koperasi dan Usaha Kecil dan Menengah, 2015). Permen KUKM ini didasarkan pada Standar Akuntansi (SAK) Umum dan Standar Akuntansi tanpa Akuntabilitas publik (SAK ETAP) yang dimodifikasi sesuai dengan tujuan dan keunikan karakteristik transaksi usaha simpan pinjam pada koperasi. Tujuan laporan keuangan menurut Permen KUKM ini adalah untuk memberikan informasi yang transparan dan bertanggungjawab atas pengelolaan usaha simpan pinjam bagi pihak-pihak yang berkepentingan seperti anggota koperasi, pemerintah, dan masyarakat. Laporan keuangan koperasi juga merupakan bentuk pertanggungjawaban pengurus atas pengelolaan sumber daya yang dipercayakan anggota kepada mereka. Koperasi yang tidak memiliki akuntabilitas publik, sehingga penerapan akuntansi keuangannya menggunakan SAK ETAP.

Standar akuntansi keuangan merupakan konstruksi dalam prosedur pembuatan laporan keuangan yang bertujuan agar ada keseragaman saat laporan keuangan disajikan (Siagian \& Pangemanan, 2016). Pada saat ini SAK ETAP merupakan standar akuntansi keuangan yang berlaku untuk koperasi. SAK ETAP ditujukan untuk digunakan oleh entitas yang tidak memiliki akuntabilitas publik (Ikatan Akuntan Indonesia, 2009). Dalam SAK ETAP bab 3 menguraikan laporan keuangan entitas antara lain neraca, laporan laba rugi, laporan perubahan ekuitas, laporan arus kas dan catatan atas laporan keuangan (Ikatan Akuntan Indonesia, 2009). Pada paragraf 2.24 SAK ETAP menjelaskan mengenai pengakuan unsur- unsur laporan keuangan yakni proses pengakuan pos yang ada di neraca maupun laporan laba rugi (Ikatan Akuntan Indonesia, 2009). Suatu pos tersebut bisa diakui jika adanya manfaat ekonomi dari pos tersebut yang akan mengalir dari entitas atau ke entitas dan pos tersebut memiliki biaya atau nilai yang bisa diukur dengan andal. Pada paragraf 2.34 sampai 2.37 SAK ETAP juga menjelaskan lebih lanjut terkait pengakuan unsur laporan keuangan (Ikatan Akuntan Indonesia, 2009). Aset diakui dalam neraca apabila di masa depan manfaat ekonomi aset 


\section{JURNALKU}

Volume 1 No. 4, Desember 2021

tersebut mengalir ke entitas. Aset tersebut juga harus memiliki nilai atau biaya yang dapat diukur dengan andal jika ingin diakui dalam neraca. Kewajiban diakui dalam neraca apabila adanya pengeluaran sumber daya yang dilakukan untuk menyelesaikan kewajiban masa kini dan jumlahnya dapat diukur dengan andal. Penghasilan diakui pada laporan laba rugi apabila adanya peningkatan manfaat ekonomi di masa depan yang terjadi akibat adanya kenaikan aset atau penurunan kewajiban yang dapat diukur dengan andal. Beban diakui pada laporan laba rugi apabila adanya manfaat ekonomi yang menurun di masa depan akibat adanya pengurangan aset atau kenaikan kewajiban yang dapat diukur dengan andal.

\section{METODE}

Penelitian ini merupakan data sekunder, yaitu berupa laporan keuangan tahun 2019 yang merupakan keputusan Rapat Anggota Tahunan KPRI X. Data diperoleh secara langsung dari pengurus KPRI X pada tanggal 7 Januari 2021. Data tahun 2020 tidak diperoleh pada saat melakukan penelitian karena pada saat penelitian dilakukan, masih belum selesai. Data diuji dengan analisis konten sebagaimana Kurniawan \& Firmansyah (2021), Saing \& Firmansyah (2021), dan Tama \& Firmansyah (2021). Analisis konten dalam penelitian ini bertujuan untuk mendapatkan data dan informasi dari laporan keuangan sebagai dasar analisis berdasarkan literatur terkait baik berupa artikel jurnal, peraturan menteri, undang-undang, dan standar akuntansi keuangan. Penelitian ini menggunakan dasar SAK ETAP dan Permen KUMK No. 13 Tahun 2015 sebagai rujukan dalam melakukan analisis terkait dengan data dan informasi yang didapatkan dari analisis konten.

\section{HASIL DAN PEMBAHASAN}

\section{Perbandingan SAK ETAP, Permen KUKM No. 13 Tahun 2015 dengan Laporan Keuangan KPRI X}

Penyajian maupun pengungkapan komponen-komponen laporan keuangan KPRI X harus mengikuti ketentuan yang diatur dalam SAK ETAP. Perbandingan komponen laporan keuangan yang dibuat oleh KPRI X dengan SAK ETAP dan Permen KUKM No. 13 Tahun 2015 terdapat dalam Tabel 1.

Tabel 1 Perbandingan Komponen Laporan Keuangan KPRI X dengan SAK ETAP, dan Permen KUKM No.13 Tahun 2015

\begin{tabular}{|c|c|c|}
\hline SAK ETAP & $\begin{array}{c}\text { Permen KUKM Nomor } 13 \\
\text { Tahun } 2015\end{array}$ & KPRI X \\
\hline Neraca & Neraca & Nerca \\
\hline Laporan laba rugi & $\begin{array}{l}\text { Laporan perhitungan hasil } \\
\text { usaha }\end{array}$ & Laporan laba rugi \\
\hline Laporan perubahan ekuitas & Laporan perubahan ekuitas & Laporan perubahan ekuitas \\
\hline Laporan arus kas & Laporan arus kas & Laporan arus kas \\
\hline Catatan atas laporan keuangan & $\begin{array}{l}\text { Catatan atas laporan } \\
\text { keuangan }\end{array}$ & Tidak ada \\
\hline
\end{tabular}

Sumber: Diolah Dari SAK ETAP, Permen KUKM No. 13 tahun 2015, dan Laporan Tahunan Pengurus dan Pengawas KPRI X

Berdasarkan Tabel 1, komponen laporan keuangan antara SAK ETAP, Permen KUKM nomor 13 tahun 2015 sudah sesuai. Terdapat perbedaan pada penamaan antara laporan laba rugi berdasarkan SAK ETAP dengan laporan perhitungan hasil usaha berdasarkan Permen KUKM No 13 Tahun 2015. Walaupun mempunyai penamaan yang berbeda namun keduanya terdiri atas komponen pendapatan dan beban. KPRI X tidak menyusun catatan atas laporan keuangan, namun membuat penjelasan akun-akun yang ada di pos neraca. 


\section{JURNALKU}

Volume 1 No. 4, Desember 2021

\section{Analisis Atas Neraca}

Bab 4 pada SAK ETAP menyebutkan bahwa komponen yang harus terdapat dalam neraca adalah aset, kewajiban, dan ekuitas. Berdasarkan tabel 2 komponen yang disajikan pada neraca KPRI X telah sesuai dengan SAK ETAP yaitu aset, kewajiban, dan ekuitas. Namun, SAK ETAP hanya menyebutkan informasi minimal yang harus disajikan dalam neraca seperti pada Tabel 2. Tidak terdapat aturan khusus yang dijelaskan SAK ETAP mengenai format atau urutan pos-pos yang disajikan dalam neraca. Sedangkan pada Permen KUKM No 13 Tahun 2015 disebutkan secara rinci akun-akun apa saja yang tersaji dalam neraca.

Tabel 2 Perbandingan Komponen Neraca SAK ETAP dengan KPRI X

\begin{tabular}{lc}
\hline \multicolumn{1}{c}{ SAK ETAP } & KPRI X \\
\hline Kas dan setara kas & Ada \\
Piutang usaha dan piutang lainnya & Ada \\
Persediaan & Ada \\
Property investasi & Tidak ada \\
Aset tetap & Ada \\
Aset tidak berwujud & Tidak ada \\
Utang usaha dan utang lainnya & Ada \\
Aset dan kewajiban pajak & Tidak ada \\
Kewajiban diestimasi & Tidak ada \\
Ekuitas & Ada \\
\hline
\end{tabular}

Sumber: Diolah Dari SAK ETAP, dan Laporan Tahunan KPRI X

Menurut SAK ETAP, yang termasuk kategori aset lancar yaitu aset yang diperkirakan akan terealisasi atau dimiliki untuk dijual maupun digunakan dalam jangka waktu 12 bulan atau satu periode akuntansi entitas. SAK ETAP tidak merinci akun-akun yang termasuk aset lancar, tetapi hanya menyebutkan minimal pos-pos yang harus disajikan. Adapun pos-pos aset lancar yang disebutkan dalam SAK ETAP yaitu kas dan setara kas, piutang usaha dan piutang lainnya, persediaan. Sementara itu, dalam Permen KUKM No 13 Tahun 2015 disebutkan secara rinci pos-pos apa saja yang harus disajikan pada neraca bagian aset lancar.

KPRI X telah menyajikan pos-pos aset lancar sesuai dengan ketentuan minimal SAK ETAP yang terdiri dari kas dan bank, piutang usaha, piutang bukan anggota piutang lain-lain dan persediaan. Perbandingan akun-akun SAK ETAP dengan akun-akun yang disajikan pada neraca KPRI X maupun pada Permen KUKM No 13 Tahun 2015 terdapat dalam Tabel 3.

Tabel 3 Perbandingan Komponen Pos Aset Lancar SAK ETAP, KPRI X, dan Permen

KUKM No. 13 tahun 2015

\begin{tabular}{lll}
\hline \multicolumn{1}{c}{ SAK ETAP } & Permen KUKM No. 13 Tahun 2015 & \multicolumn{1}{c}{ Neraca KPRI X } \\
\hline Kas dan setara kas & Kas & Kas dan bank \\
$\begin{array}{l}\text { Piutang usaha dan piutang } \\
\text { lainnya }\end{array}$ & Penempatan Dana pada & Piutang usaha \\
Persediaan & Bank & \\
Aset pajak & Surat berharga & Piutang bukan anggota \\
& Pinjaman yang diberikan piutang tak tertagih \\
& Penyisihan pinjaman tak tertagih & Cadangang lain-lain \\
& Perlengkapan & Persediaan \\
& Pajak dibayar dimuka & Biaya dibayar dimuka \\
& Biaya dibayar dimuka & \\
& Pendapatan yang Masih & \\
& Harus Diterima & \\
& Aset Lancar Lain & \\
\hline
\end{tabular}




\section{JURNALKU}

Volume 1 No. 4, Desember 2021

Sumber: Diolah Dari SAK ETAP, Permen KUKM No. 13 tahun 2015, dan Laporan

Tahunan Pengurus dan Pengawas KPRI X.

KPRI X menyajikan akun kas dan bank, sedangkan pada SAK ETAP nama akun yang disajikan bernama kas dan setara kas. KPR X hanya mempunyai kas dan kas yang berada di bank saja, tidak memiliki setara kas atau investasi jangka pendek yang sangat likuid. Kas yang terdapat dalam neraca KPRI X merupakan kas yang ada di tangan KPRI X, sedangkan bank yaitu kas milik KPRI X yang disimpan di bank. Dalam Permen KUKM No 13 Tahun 2015 terdapat akun tersendiri bernama penempatan dana pada bank yang merupakan simpanan koperasi pada bank tertentu. Sementara itu, dalam neraca KPRI X, akun kas dan bank digabung menjadi satu akun. Penyajian dan pencatatan kas KPRI X telah sesuai dengan SAK ETAP namun belum diungkapkan ke dalam CaLK.

KPRI X membagi piutangnya menjadi tiga pos akun piutang, yaitu piutang usaha, piutang bukan anggota, dan piutang lain-lain. Piutang usaha KPRI X berasal dari hasil aktivitas usaha koperasi yang diberikan kepada pihak lain baik berupa barang maupun jasa tetapi pembayarannya belum diterima oleh koperasi. Penyajian piutang usaha disajikan sebesar saldo kotor sebelum dikurangi dengan taksiran kemungkinan tidak tertagihnya piutang.

SAK ETAP menyebutkan hanya satu akun yaitu piutang usaha dan piutang lain- lain. Cadangan piutang tak tertgih tidak dijelaskan pengertiannya, sedangkan pada Permen KUKM No 13 Tahun 2015 menjelaskan definisi cadangan piutang tak tertagih sebagai penyisihan nilai tertentu sebagai pengurang nilai nominal piutang. Hal ini dilakukan atas dasar kemungkinan risiko tidak tertagihnya piutang. Permen KUKM No 13 Tahun 2015 mencatat cadangan piutang tak tertagih sebagai penyisihan pinjaman tak tertagih. Dapat ditarik kesimpulan penyajian pos piutang usaha pada neraca KPRI X sudah sesuai dengan SAK ETAP dan Permen KUKM No 13 Tahun 2015.

Menurut SAK ETAP pos minimal yang ada di neraca salah satunya adalah persediaan. Persediaan merupakan aset yang bertujuan untuk dijual dalam kegiatan usaha normal atau dalam proses produksi untuk kemudian dijual. Dalam Permen KUKM No 13 Tahun 2015 tidak menjelaskan mengenai akun persediaan namun pada Permen KUKM No 12 Tahun 2015 tentang pedoman akuntansi koperasi riil menyebutkan komponen aset lancar salah satunya adalah persediaan. KPRI X mengakui pos persediaan sebagai aset lancar dan dicatat sebesar nilai perolehannya. Berdasarkan penjelasan tersebut, pos persediaan sudah disajikan sesuai dengan SAK ETAP.

SAK ETAP tidak menjelaskan mengenai biaya dibayar dimuka, namun menurut Permen KUKM No 13 Tahun 2015 biaya dibayar dimuka adalah biaya yang dibayar diawal kepada pihak lain ketika memperoleh manfaat atas barang/jasa tersebut. Pada neraca KPRI X pos akun biaya dibayar dimuka diakui sebagai aset lancar dan bersaldo nol. pos biaya dibayar dimuka telah sesuai dengan Permen KUKM No 13 Tahun 2015.

SAK ETAP telah menentukan komponen minimal yang ada dalam aset tidak lancar. pada Permen KUKM No 13 Tahun 2015 juga merinci lebih banyak akun-akun yang ada dalam pos aset tidak lancar. Pada Tabel 4 menunjukan perbandingan penyajian aset tidak lancar antara KPRI X dengan SAK ETAP dan Permen KUKM No 13 Tahun 2015. 


\section{JURNALKU}

Volume 1 No. 4, Desember 2021

Tabel 4 Perbandingan Komponen Pos Aset Tidak Lancar SAK ETAP, KPRI X, dan Permen KUKM No. 13 Tahun 2015

\begin{tabular}{lll}
\hline \multicolumn{1}{c}{ SAK ETAP } & Permen KUKM No 13 Tahun 2015 & \multicolumn{1}{c}{ KPRI X } \\
\hline Aset tidak lancar & Aset tidak lancar & Investasi jangka panjang \\
$\begin{array}{l}\text { Properti investasi } \\
\text { Aset tetap }\end{array}$ & Asvestasi jangka panjang & $\begin{array}{c}\text { Akumulasi penyusutan aset } \\
\text { tetap }\end{array}$ \\
Aset tidak berwujud & Properti investasi & Aset lain-lain \\
& Akumulasi Penyusutan & \\
& Properti Investasi & \\
& Aset tetap & \\
& Akumulasi Penyusutan Aset & \\
& Tetap & \\
& Aset tidak berwujud & \\
& Akumulasi amortisasi Aset & \\
& Tidak Berwuiud & \\
& & \\
\end{tabular}

Sumber: Diolah Dari SAK ETAP, Permen KUKM No. 13 tahun 2015, dan Laporan

Tahunan Pengurus dan Pengawas KPRI X

KPRI X memiliki format yang berbeda yaitu memisahkan aset tidak lancar menjadi investasi jangka Panjang, aset tetap, dan aset lain-lain. Namun, SAK ETAP tidak menentukan format atau urutan terhadap pos-pos yang disajikan dalam neraca. Pos yang terpisah dibenarkan jika sifat, ukuran, atau fungsi dari pos terhadap pos-pos yang serupa membuat penyajian terpisah menjadi andal dan relevan untuk memahami posisi keuangan entitas.

SAK ETAP menyebutkan pos properti investasi sebagai komponen minimal yang ada di neraca tetapi tidak menyebutkan pos investasi jangka Panjang. Karena KPRI X tidak mempunyai properti yang tujuannya untuk investasi, maka KPRI X tidak menyajikan akun properti investasi dalam neracanya. KPRI X hanya memiliki investasi jangka panjang dalam bentuk simpanan pada lembaga koperasi dan simpanan pada lembaga non koperasi. Investasi jangka panjang dikategorikan sebagai aset tidak lancar karena pencairannya butuh waktu lebih dari setahun atau satu periode akuntansi. Hal ini sudah sesuai dengan Permen KUKM No 13 tahun 2015.

SAK ETAP mendefinisikan aset tetap sebagai aset berwujud yang dimiliki untuk digunakan dalam produksi atau penyediaan barang atau jasa, untuk disewakan ke pihak lain, atau untuk tujuan administratif dan memiliki umur manfaat lebih dari satu periode. Sejalan dengan SAK ETAP, aset tetap KPRI X merupakan aset berwujud yang digunakan dalam kegiatan operasi, tidak untuk dijual dan mempunyai umur manfaat lebih dari satu periode akuntansi. Aset tetap KPRI X terdiri dari bangunan, kendaraan, dan peralatan yang dicatat sebesar harga perolehan dan disajikan pada pos aset tetap dalam neraca. Aset tetap dicatat sebesar nilai kotor belum dikurangi dengan akumulasi penyusutan aset tetap. Penyajian pos aset tetap pada neraca KPRI X telah sesuai dengan SAK ETAP.

Permen KUKM No 13 Tahun 2015 menjelaskan akumulasi penyusutan sebagai pengurang nilai perolehan aset tetap koperasi. Akumulasi penyusutan diakui secara sistematis dari awal penggunaan Aset tetap sampai dengan umur masa manfaatnya. Pada neraca KPRI $\mathrm{X}$ akun akumulasi penyusutan disajikan dalam pos aset tetap sebagai pengurang akun aset tetap. Namun akumulasi penyusutan ini tidak dirinci per aset tetap melainkan digabung menjadi satu akun yang bernama akumulasi penyusutan aset tetap. Penyajian pos akumulasi penyusutan pada neraca KPRI X telah sesuai dengan Permen KUKM N0. 13 Tahun 2015. Pada Permen KUKM No 13 Tahun 2015 mencatat aset lain-lain sebagai aset tidak lancar lain A yaitu aset yang tidak termasuk kedalam aset tidak lancar yang sudah disebutkan pada klasifikasi sebelumnya. Pada neraca KPRI X, aset lain-lain disajikan dalam neraca namun memiliki saldo nol. 


\section{JURNALKU}

Volume 1 No. 4, Desember 2021

SAK ETAP entitas mengklasifikasikan kewajiban kedalam kewajiban jangka pendek dan kewajiban jangka Panjang, namun tidak menyebutkan secara rinci pos-pos yang termasuk dalam kewajiban jangka pendek maupun jangka Panjang. Sementara itu, permen KUKM No 13 Tahun 2015 mengatur pos-pos apa saja yang masuk dalam klasifikasi kewajiban jangka pendek dan kewajiban jangka Panjang. Perbandingan pos-pos kewajiban yang disajikan KPRI X dengan SAK ETAP dan Permen KUKM No 13 tahun 2015 sebagaimana dalam Tabel 5.

Tabel 5 Perbandingan Komponen Pos Kewajiban SAK ETAP, KPRI X, dan Permen KUKM No. 13 Tahun 2015

\begin{tabular}{|c|c|c|}
\hline SAK ETAP & Permen KUKM No 13 tahun 2015 & KPRI X \\
\hline Kewajiban: & Kewajiban & Kewajiban \\
\hline $\begin{array}{l}\text { Utang usaha dan utang } \\
\text { lainnya }\end{array}$ & Kewajiban jangka pendek & jangka pendek \\
\hline Kewajiban pajak & Simpanan anggota & Simpanan anggota \\
\hline \multirow{9}{*}{$\begin{array}{l}\text { Kewajiban } \\
\text { diestimasi }\end{array}$} & Dana-dana Bagian dari SHU & Hutang bukan anggota \\
\hline & Hutang Pajak & Dana-dana SHU \\
\hline & $\begin{array}{l}\text { Hutang Bank/Lembaga } \\
\text { Keuangan Lain }\end{array}$ & Dana-dana \\
\hline & $\begin{array}{l}\text { Beban yang masih harus dibayar } \\
\text { Pendapatan diterima dimuka }\end{array}$ & Simpanan sukarela \\
\hline & Hutang jangka pendek lainnya & $\begin{array}{l}\text { Kewajiban } \\
\text { Panjang }\end{array}$ \\
\hline & Kewajiban jangka Panjang & Hutang bukan anggota \\
\hline & $\begin{array}{l}\text { Hutang bank/Lembaga keuangan } \\
\text { lain/KSP Sekunder }\end{array}$ & Hutang bank \\
\hline & Modal penyertaan & \\
\hline & Kewajiban jangka panjang lainnya & \\
\hline
\end{tabular}

Sumber: Diolah Dari SAK ETAP, Permen KUKM No. 13 tahun 2015, dan Laporan

Tahunan Pengurus dan Pengawas KPRI X

Menurut Permen KUKM No 13 Tahun 2015 kewajiban jangka pendek adalah utang yang harus dilunasi kurang dari satu periode dan dimiliki untuk keperluan modal kerja. contoh pos kewajiban jangka pendek salah satunya yakni simpanan anggota KPRI Xmenyajikan akunakun kewajiban jangka pendek meliputi, simpanan anggota, hutang bukan anggota, dana-dana SHU, dana- dana, simpanan sukarela, dan Biaya yang masih harus dibayar. KPRI X telah mencatat pos ini sesuai dengan ketentuan tersebut yaitu dicatat sebagai simpanan anggota. Transaksi ini diakui sebagai kewajiban jangka pendek dan diukur sebesar nilai nominalnya. Simpanan anggota KPRI X meliputi simpanan khusus, simpanan lain-lain, simpanan anggota (tabungan), dan simpanan berjangka.

Akun hutang bukan anggota pada neraca KPRI X merupakan kewajiban kepada anggota maupun bukan anggota yang timbul karena aktivitas usaha koperasi berupa pembelian barang secara non tunai oleh koperasi. Pos ini telah sesuai dengan SAK ETAP yang menyebutkan komponen minimal tersaji di neraca salah satunya adalah utang usaha. Walaupun mempunyai penamaan yang berbeda tetapi berdasarkan penjelasan mengenai akun utang bukan anggota, keduanya memiliki definisi yang sama. Oleh karena itu, antara akun utang bukan anggota dengan akun utang usaha bisa dipersamakan.

SAK ETAP tidak menjelaskan terkait akun Dana-dana SHU. Namun, Permen KUKM No 13 tahun 2015 telah menjelaskan tentang akun dana-dana SHU yang dicatat dalam peraturan tersebut sebagai akun dana-dana bagian dari SHU. akun ini dicatat sebagai kewajiban jangka pendek dan disajikan sebesar nilai nominalnya. Dana-dana SHU KPRI X mencakup dana 


\section{JURNALKU}

Volume 1 No. 4, Desember 2021

sosial, dana pengembangan koperasi, dan dana pendidikan. Dana sosial merupakan alokasi SHU yang belum dibagikan dalam rangka kegiatan sosial KPRI X seperti sumbangan bencana alam. Dana pembangunan koperasi merupakan alokasi SHU yang belum dibagikan dalam rangka pembangunan KPRI X. Dana Pendidikan merupakan alokasi SHU yang belum dibagikan dalam rangka mengembangkan sumber daya manusia KPRI X dalam bidang pendidikan. Berdasarkan Permen KUKM No 13 Tahun 2015 penyajian akun dana-dana SHU telah sesuai ketentuan.

Akun dana-dana lainnya pada neraca KPRI X terpisah dari akun dana-dana SHU. Akun ini diklasifikasikan dalam pos kewajiban jangka pendek. Dana-dana lainnya terdiri dari dana kematian anggota, dana kesejahteraan khusus dan dana purna tugas. Akun dana-dana seharusnya disajikan menjadi satu kedalam akun Dana-dana SHU. Walaupun demikian penyajian akun dana-dana telah disajikan pada pos kewajiban jangka pendek jadi sudah memenuhi Permen KUKM No 13 tahun 2015.

Dalam Permen KUKM No 13 tahun 2015, simpanan sukarela masuk kedalam pos simpanan anggota. Pada neraca KPRI $\mathrm{X}$ akun simpanan anggota dan simpanan sukarela disajikan terpisah, seharusnya kedua akun tersebut disajikan menjadi satu pada akun simpanan anggota. Maka dari itu, penyajian akun simpanan sukarela belum sesuai dengan Permen KUKM No 13 Tahun 2015.

Akun Biaya yang masih harus dibayar pada Permen KUKM No 13 Tahun 2015 dicatat sebagai akun beban yang masih harus dibayar. Pengakuan akun ini disajikan dalam pos kewajiban jangka pendek dan disajikan sesuai nominalnya. Biaya yang masih harus dibayar pada KPRI X yakni biaya pajak yang sudah terjadi namun belum dibayar. Penyajian atas akun ini telah sesuai dengan Permen KUKM No 13 Tahun 2015.

Menurut Permen KUKM No 13 tahun 2015 menjelaskan definisi kewajiban jangka panjang ialah utang koperasi yang dilunasi dalam jangka waktu lebih dari satu periode dan dimiliki untuk kebutuhan investasi atau kebutuhan lainnya. KPRI X mempunyai dua akun yang termasuk dalam kategori kewajiban jangka panjang. Akun tersebut adalah utang bukan anggota, dan utang bank. Hutang bukan anggota X meliputi titipan potongan gaji, titipan dana asuransi bumi putera, dan titipan asuransi. Akun ini masuk ke dalam pos kewajiban jangka panjang dan dicatat sebesar nilai nominalnya. Walaupun memp unyai penamaan yang berbeda namun kedua akun ini dapat dipersamakan karena jenis dan sifatnya sama. Maka dari itu penyajian akun utang bukan anggota sudah sesuai dengan permen KUKM No 13 Tahun 2015.

Neraca KPRI X menyajikan akun utang bank. SAK ETAP tidak mengatur lebih lanjut mengenai akun ini, namun dalam Permen KUKM No 13 Tahun 2015 sudah dijelaskan. Akun ini diklasifikasikan sebagai kewajiban jangka Panjang dan dicatat sebesar nilai nominalnya. Akun hutang bank pada neraca KPRI X mengidentifikasikan kewajiban yang dimiliki koperasi pada bank BPD. Pengakuan dan penyajian akun ini sudah sesuai dengan Permen KUKM No 13 Tahun 2015.

Dalam Bab 19 SAK ETAP menyebutkan bahwa ekuitas selaku porsi atas hak pemilik harus dilaporkan sedemikian rupa sehingga memberikan informasi secara jelas tentang sumbernya. Ekuitas juga harus disajikan sesuai dengan peraturan perundangan dan akta pendirian yang berlaku. Dalam hal ini peraturan perundangan yang berlaku sebagai pedoman penyajian ekuitas adalah Permen KUKM No. 13 Tahun 2015. SAK ETAP tidak menjelaskan lebih lanjut mengenai komponen-komponen ekuitas pada koperasi, melainkan hanya menyebutkan saja. Pada paragraf 19.3 SAK ETAP menyebutkan ekuitas atau kekayaan bersih koperasi terdiri dari simpanan pokok, simpanan lain, cadangan, pinjaman-pinjaman, dan penyisihan hasil usaha. Perbandingan komponen ekuitas KPRI X dengan SAK ETAP dan Permen KUKM No 13 tahun 2015 bisa dilihat pada Tabel 6. 


\section{JURNALKU}

Volume 1 No. 4, Desember 2021

SAK ETAP menentukan bahwa akuntansi ekuitas atas badan usaha bukan PT dilaporkan berdasarkan peraturan perundangan yang berlaku untuk badan yang bersangkutan. Dalam hal ini pelaporan akuntansi ekuitas koperasi diatur lebih lanjut dalam Permen KUKM No 13 tahun 2015. Berdasarkan perbandingan penyajian komponen ekuitas pada tabel 6, KPRI X sudah menyajikan komponen ekuitas sesuai dengan peraturan yang ada. Ada perbedaan perihal pencatatan nama akun komponen ekuitas yang disajikan dalam neraca KPRIX dengan permen KUKM No 13 Tahun 2015 yaitu modal donasi dengan hibah/sumbangan. Modal donasi pada neraca KPRI X merupakan modal yang diperoleh dari donasi baik uang maupun barang yang mempunyai nilai nominal dapat diukur. Donasi ini diterima dari pihak lain dan dicatat sebesar nilai nominalnya. Kedua akun ini bisa dipersamakan karena mempunyai definisi yang serupa.

Tabel 6 Perbandingan Komponen Pos Ekuitas SAK ETAP, KPRI X, dan Permen

KUKM No. 13 Tahun 2015

\begin{tabular}{lll}
\hline \multicolumn{1}{c}{ SAK ETAP } & Permen KUKM No 13 Tahun 2015 & \multicolumn{1}{c}{ KPRI X } \\
\hline Ekuitas & Ekuitas & Ekuitas \\
Simpanan pokok & Simpanan pokok & Simpanan pokok \\
Simpanan lain & Simpanan wajib & Simpanan wajib \\
Cadangan & Cadangan & Cadangan \\
Pinjaman-pinjaman & Hibah/sumbangan & Modal donasi \\
Penyisihan hasil usaha & SHU tahun berjalan & SHU tahun berjalan \\
\hline
\end{tabular}

Sumber: Diolah Dari SAK ETAP, Permen KUKM No. 13 Tahun 2015, dan Laporan

Tahunan Pengurus dan Pengawas KPRI X

\section{Analisis Atas Laporan Sisa Hasil Usaha}

Hasil kinerja keuangan sebuah koperasi disebut sebagai sisa hasil usaha yang merupakan selisih antara pendapatan dan beban koperasi selama satu periode. Bab 5 SAK ETAP mewajibkan sebuah entitas membuat laporan laba rugi yang menunjukan hasil kinerja keuangannya selama periode yang bersangkutan. Laporan laba rugi harus memasukan semua pos pendapatan dan beban yang diakui dalam suatu periode kecuali SAK mensyaratkan lain. Laporan Laba rugi suatu koperasi tercermin dalam laporan sisa hasil usaha.

Perbandingan komponen laporan sisa hasil usaha yang dibuat KPRI X dan berdasarkan SAK ETAP dan Permen KUKM No. 13 Tahun 2015 sebagaimana dalam Tabel 7.

Tabel 7 Perbandingan Komponen Laporan Perhitungan Sisa Hasil Usaha menurut SAK ETAP, KPRI X, dan Permen KUKM No 13 Tahun 2015

\begin{tabular}{lll}
\hline \multicolumn{1}{c}{ SAK ETAP } & Permen KUKM No 13 Tahun 2015 & \multicolumn{1}{c}{ KPRI X } \\
\hline Pendapatan & Pendapatan operasional utama & Pendapatan usaha \\
Beban keuangan & Pendapatan operasional lainnya & HPP \\
$\begin{array}{l}\text { Bagian laba atau rugi dari investasi } \\
\text { yang menggunakan metode ekuitas }\end{array}$ & Beban operasional & Beban usaha \\
Beban pajak & Pendapatan lainnya & Pendapatan luar usaha \\
Laba atau rugi neto & Beban lainnya & beban luar usaha \\
& Beban pajak & Pajak penghasilan badan \\
& Sisa hasil usaha & SHU setelah pajak \\
\hline
\end{tabular}

Sumber: Diolah Dari SAK ETAP, Laporan Tahunan Pengurus dan Pengawas

KPRI X, dan Permen KUKM No 13 Tahun 2015

Tidak ada format atau urutan terhadap pos-pos yang disajikan. Namun SAK ETAP menyebutkan bahwa entitas harus menyajikan pos, judul, dan sub jumlah lainnya pada laporan laba rugi jika penyajian tersebut relevan untuk memahami kinerja keuangan entitas. Berdasarkan Bab 7 Permen KUKM No 13 Tahun 2015 komponen pendapatan memisahkan antara pendapatan operasional dengan pendapatan operasional lainnya. Dalam laporan sisa hasil usaha KPRI X tidak memisahkan akun pendapatan operasional utama dengan pendapatan 


\section{JURNALKU}

Volume 1 No. 4, Desember 2021

operasional lainnya melainkan mencatat pada satu akun yaitu akun pendapatan usaha. Walaupun belum sesuai dengan permen KUKM No 13 Tahun 2015, namun penyajian ini telah sesuai dengan SAK ETAP yang menetapkan pos pendapatan sebagai komponen minimal laporan laba rugi.

Bab 20 SAK ETAP memaparkan ruang lingkup pendapatan adalah penghasilan yang muncul bersumber dari transaksi penjualan barang, pemberian jasa, kontrak konstruksi, dan penggunaan aset entitas oleh pihak lain yang menghasilkan bunga, royalti atau dividen. Pendapatan usaha KPRI X bersumber dari kegiatan usaha dalam pelayanan jasa dan penjualan barang dagangan baik kepada anggota maupun non anggota. Sehingga dapat dikatakan bahwa penyajian dan pengungkapan akun pendapatan pada KPRI X sudah sesuai SAK ETAP.

Bab 7 Permen KUKM No 13 Tahun 2015 hanya memisahkan komponen beban menjadi beban operasional, beban lainnya, dan beban pajak. Pada Permen tersebut tidak terdapat komponen harga pokok penjualan (HPP) karena permen tersebut mengatur mengenai koperasi simpan pinjam saja, sedangkan aktivitas usaha KPRI X selain simpan pinjam juga mempunyai aktivitas utama lain seperti koperasi konsumen. Dalam laporannya KPRI X menyajikan HPP pada laporan sisa hasil usahanya. SAK ETAP tidak menerangkan terkait HPP ini, tetapi menyebutkan pos beban keuangan merupakan salah satu komponen minimal yang ada di laporan laba-rugi. Paragraf 2.20 SAK ETAP mendefinisikan beban sebagai penurunan manfaat ekonomi dalam bentuk penurunan aset maupun peningkatan kewajiban selama satu periode pelaporan. Sesuai dengan definisi tersebut, HPP termasuk dalam kategori beban karena ada arus kas keluar atau penurunan aset ketika HPP diakui. KPRI X mengeluarkan uang tunai maupun menambah kewajiban ketika membeli barang dagangan untuk keperluan usaha koperasi. Penulis dapat menyimpulkan bahwa penyajian HPP pada laporan sisa hasil usaha KPRI X telah sesuai dengan SAK ETAP.

Pos beban usaha pada laporan sisa hasil usaha KPRI X meliputi beban unit, beban organisasi dan beban kantor. Dalam Permen KUKM No 13 mencatat beban usaha sebagai beban operasional yang meliputi beban usaha dan beban perkoperasian. Meskipun mempunyai penamaan yang berbeda dengan Permen KUKM No 13 Tahun 2015 tetapi KPRI $\mathrm{X}$ telah menyajikan beban dalam suatu klasifikasi berdasarkan fungsi sehingga informasi lebih andal dan relevan. Pernyataan ini sejalan dengan paragraf 5.6 SAK ETAP. Jadi, penyajian beban usaha pada laporan sisa hasil usaha KPRI X telah sesuai dengan SAK ETAP.

Permen KUKM No 13 Tahun 2015 mencatat akun pendapatan luar usaha sebagai pendapatan lainnya. Pendapatan luar usaha pada laporan sisa hasil usaha KPRI X berasal dari pendapatan jasa giro dan pendapatan lain-lain yang keduanya bukan merupakan pendapatan dari aktivitas utama kegiatan koperasi. Meskipun mempunyai pencatatan yang berbeda, tetapi akun pendapatan luar usaha dengan pendapatan lainnya bisa dipersamakan karena memiliki definisi dan fungsi yang sama.

Permen KUKM No 13 Tahun 2015 mencatat akun beban luar usaha sebagai beban lainnya. Beban luar usaha pada laporan sisa hasil usaha KPRI X terdiri dari beban lain-lain. Permen KUKM No 13 Tahun 2015 mendefinisikan beban lainnya sebagai beban yang dikeluarkan oleh koperasi sehubungan dengan pelaksanaan kegiatan usaha yang bukan merupakan aktivitas utama usaha koperasi. Penyajian akun ini telah sesuai dengan ketentuan yang berlaku.

SAK ETAP mencatat pajak penghasilan badan dengan beban pajak, sama seperti Permen KUKM No 13 Tahun 2015. Definisi beban pajak menurut SAK ETAP adalah jumlah agregat yang termasuk dalam penentuan laba atau rugi untuk periode pajak kini. Akun ini telah disajikan sesuai dengan SAK ETAP. SAK ETAP mencatat sisa hasil usaha sebagai laba atau rugi entitas. Menurut Permen KUKM No 13 Tahun 2015 sisa hasil usaha adalah semua pendapatan operasional utama dikurangi dengan beban operasional usaha dan beban lainnya 


\section{JURNALKU}

Volume 1 No. 4, Desember 2021

setelah pajak. KPRI X telah menyajikan sisa hasil usaha sesuai dengan SAK ETAP maupun Permen KUKM No 13 Tahun 2015.

\section{Analisis Atas Laporan Perubahan Ekuitas}

Menurut paragraf 6.3 SAK ETAP informasi yang perlu disajikan pada laporan perubahan ekuitas meliputi laba atau rugi periode berjalan, pendapatan dan beban yang diakui langsung dalam ekuitas, pengaruh perubahan kebijakan akuntansi dan koreksi kesalahan yang diakui untuk setiap komponen ekuitas, dan rekonsiliasi antara jumlah tercatat awal dan akhir periode, serta diungkapkan secara terpisah. SAK ETAP tidak menyebutkan secara rinci pospos yang ada pada laporan perubahan ekuitas. Oleh karena itu, penelitian ini membandingkan format dan komponen laporan perubahan ekuitas dalam akuntansi koperasi simpan pinjam berdasarkan Permen KUKM No 13 Tahun 2015. Tabel 8 merupakan perbandingan penyajian laporan perubahan ekuitas yang disajikan KPRI X dengan Permen KUKM No. 13 Tahun 2015. Baik KPRI X maupun Permen KUKM No 13 Tahun 2015 telah memuat informasi yang perlu disajikan pada laporan perubahan ekuitas.

Tabel 8 Perbandingan Komponen Laporan Perubahan Ekuitas Menurut Permen

KUKM No 13 Tahun 2015 dan KPRI X

\begin{tabular}{ll}
\hline \multicolumn{1}{c}{ Permen KUKM No 13 Tahun 2015 } & \multicolumn{1}{c}{ KPRI X } \\
\hline Simpanan pokok & Simpanan pokok \\
Simpanan wajib & Simpanan wajib \\
Cadangan & Cadangan koperasi \\
Hibah & Modal donasi/ hibah \\
SHU yang tidak dibagikan pada periode & SHU Tahun Berjalan \\
akuntansi & \\
\hline
\end{tabular}

Sumber: Diolah Dari Permen KUKM No 13 Tahun 2015 dan Laporan Tahunan Pengurus dan Pengawas KPRI X

Penyajian pos-pos pada laporan perubahan ekuitas KPRI X telah sesuai dengan SAK ETAP karena laporan perubahan ekuitas tersebut sudah menyajikan informasi yang wajib disajikan dalam laporan perubahan ekuitas yang diatur dalam SAK ETAP.

Analisis Atas Laporan Arus Kas

SAK ETAP mengidentifikasikan laporan arus kas sebagai laporan keuangan yang menyajikan informasi tentang perubahan kas dan setara kas suatu entitas selama periode tertentu. Perubahan yang disajikan harus menunjukan secara terpisah dari aktivitas operasi, aktivitas investasi, dan aktivitas pendanaan. Sesuai dengan SAK ETAP, KPRI X mengklasifikasikan laporan arus kasnya menjadi aktivitas operasi dan aktivitas pendanaan. KPRI X tidak menyajikan laporan arus kas menurut aktivitas investasi karena tidak memiliki aktivitas investasi seperti pembelian dan penjualan aset tetap atau penyertaan modal dalam bentuk investasi jangka panjang.

Permen KUKM No 13 Tahun 2015 Bab 9 menyebutkan bahwa laporan arus kas bisa disusun menggunakan dua metode, yaitu metode langsung dan metode tidak langsung. Laporan arus kas yang dibuat oleh KPRI X menggunakan metode tidak langsung. Menurut paragraf 7.9 SAK ETAP, dalam metode tidak langsung, arus kas neto dari aktivitas operasi entitas ditentukan dengan menyesuaikan laba atau rugi dari dampak perubahan pada akun persediaan, piutang usaha dan utang usaha selama periode berjalan; pos non kas seperti keuntungan dan kerugian valuta asing yang belum direalisasi, penyusutan, dan penyisihan; dan semua pos lain yang berkaitan dengan arus kas investasi atau pendanaan.

Jika ditinjau dari SAK ETAP, penyajian laporan arus kas KPRI X telah sesuai dengan ketentuan yang diatur dalam SAK ETAP. Arus kas pada aktivitas operasi KPRI X ditentukan dengan melakukan penyesuaian atas sisa hasil usaha tahun berjalan. KPRI X melakukan Penyesuaian atas SHU tahun berjalan atas aktivitas operasi dengan cara mengurangi atau 


\section{JURNALKU}

Volume 1 No. 4, Desember 2021

menambah perubahan dari utang usaha, penyisihan piutang tak tertagih, persediaan, dana-dana SHU, simpanan sukarela, simpanan anggota, utang dagang, simpanan pada lembaga koperasi, beban penyusutan aktiva tetap. Selain itu, KPRI X juga menyesuaikan arus kas aktivitas operasinya dengan aktivitas pendanaan yang terdiri dari penurunan simpanan pokok, kenaikan simpanan wajib, kenaikan cadangan dan SHU tahun lalu. Dengan demikian, KPRI X sudah menyajikan laporan arus kas sesuai dengan SAK ETAP.

\section{PENUTUP}

\section{Simpulan}

KPRI X telah menyajikan komponen aset, kewajiban dan ekuitas di dalam neracan. SAK ETAP tidak menentukan format atau urutan terhadap pos-pos yang disajikan melainkan hanya menyediakan daftar pos-pos yang berbeda baik sifat atau fungsinya. KPRI X telah menyajikan secara terpisah pos-pos pada neraca sesuai dengan fungsi dan sifatnya, sehingga membuat penyajian neraca lebih relevan dan andal. Neraca KPRI X menyajikan pos aset yang terdiri dari aset lancar, investasi jangka panjang, aset tetap, dan aset lain-lain, pos kewajiban terdiri dari kewajiban jangka pendek, kewajiban jangka panjang, dan pos ekuitas. Komponen-komponen yang disajikan KPRI X sudah memenuhi komponen minimal dalam neraca menurut SAK ETAP. Namun, terdapat beberapa komponen yang tidak disajikan dalam neraca KPRI X yakni properti investasi, aset tidak berwujud, kewajiban pajak, dan kewajiban yang diestimasi. Kondisi ini terjadi karena koperasi tidak memiliki sumber daya yang dapat diidentifikasikan sebagai komponen atau pos tersebut. Secara keseluruhan, penyajian, pengakuan dan pengklasifikasian pos-pos yang ada di neraca KPRI X telah sesuai dengan SAK ETAP dan Permen KUKM No 13 Tahun 2015.

Dalam SAK ETAP, laporan perhitungan sisa hasil usaha disebut sebagai laporan laba rugi. Komponen minimal laba rugi yang disebutkan dalam SAK ETAP telah disajikan dengan lengkap pada laporan perhitungan hasil usaha KPRI X kecuali pos bagian laba atau rugi dari investasi yang menggunakan metode ekuitas. KPRI X tidak mencatat pos tersebut karena tidak memiliki sumber daya yang dapat diidentifikasikan sebagai pos tersebut. Akun-akun laporan sisa hasil usaha koperasi disebutkan lebih rinci dalam Permen KUKM No. 13 Tahun 2015. Terdapat perbedaan pencatatan nama akun antara Permen KUKM No. 13 Tahun 2015 dengan akun-akun pada laporan perhitungan sisa hasil usaha KPRI X, namun hal ini tidak mengakibatkan terjadinya kesalahan karena secara subtansi keduanya memiliki jenis, sifat, dan definisi yang serupa. Secara keseluruhan, penyajian, pengakuan dan pengklasifikasian pos-pos yang ada di Laporan Perhitungan Sisa Hasil Usaha KPRI X telah sesuai dengan SAK ETAP dan Permen KUKM No 13 Tahun 2015. SAK ETAP tidak menyebutkan komponen minimal pada laporan perubahan ekuitas melainkan hanya menyebutkan informasi yang perlu diungkapkan dalam laporan perubahan ekuitas. Laporan perubahan ekuitas KPRI X telah berhasil menyajikan data dan informasi sebagaimana SAK ETAP dan Permen KUKM No 13 tahun 2015

SAK ETAP mengklasifikasikan arus kas menurut aktivitasnya, yaitu aktivitas operasional, aktivitas investasi, dan aktivitas pendanaan. KPRI X membagi aktivitas arus kas masuk maupun keluar menjadi dua bagian yaitu arus kas dari aktivitas operasi dan arus kas dari aktivitas pendanaan. KPRI $\mathrm{X}$ tidak mencatat arus kas dari aktivitas investasi karena tidak memiliki transaksi kas yang berhubungan dengan aktivitas investasi. KPRI X juga menyajikan laporan arus kasnya dengan metode tidak langsung. Penyajian pos-pos pada laporan arus kas sudah sesuai dengan SAK ETAP. Selanjutnya, KPRI X tidak menyusun catatan atas laporan keuangan tersendiri tetapi telah membuat penjelasan atas akun-akun yang terdapat pada pos neraca. 


\section{JURNALKU}

Volume 1 No. 4, Desember 2021

\section{Saran}

Penelitian ini hanya terbatas pada satu entitas koperasi simpan pinjam dan hanya menggunakan metode analisis konten. Penelitian selanjutnya dapat menggunakan entitas koperasi lainnya atau beberapa entitas koperasi dan melakukan wawancara dengan pihak-pihak terkait untuk mendapatkan hasil yang lebih baik dan komprehensif. Penelitian ini mengindikasikan kepada Ikatan Akuntan Indonesia dan Kementerian Koperasi dan Usaha Kecil dan Menengah untuk melakukan koordinasi dalam penyusunan standar akuntansi keuangan untuk koperasi di Indonesia, sehingga terdapat standar akuntansi keuangan tunggal yang dapat dirujuk oleh seluruh entitas koperasi.

\section{DAFTAR PUSTAKA}

Fatmawati, A. P., \& Maulana, J. (2021). Analisis penerapan SAK Koperasi Pasca Pencabutan PSAK 27 tentang penyajian laporan keuangan Koperasi Pegawai Republik Indonesia (KPRI) UPI Bandung. Accounthink: Journal of Accounting and Finance, 5(1), 25-28. https://emea.mitsubishielectric.com/ar/products-solutions/factory-automation/index.html

Handayani, D. Y., Mintarti, S., \& Musviyanti, M. (2017). Analisis penyajian laporan keuangan berdasarkan standar akuntansi keuangan entitas tanpa akuntabilitas publik. Jurnal Ilmu Akuntansi Mulawarman, 2(2). https://doi.org/10.29264/jiam.v2i2.1067

Ikatan Akuntan Indonesia. (2009). Standar Akuntansi Keuangan untuk Entitas Tanpa Akuntabilitas Publik (SAK ETAP). Ikatan Akuntan Indonesia.

Indawatika, F. (2017). Penyusunan laporan keuangan berbasis SAK ETAP Koperasi Intako dan respon pihak eksternal. Journal of Accounting Science, 1(1), 38-50. https://doi.org/10.21070/jas.v1i1.788

Kader, M. A. (2018). Peran UKM dan koperasi dalam mewujudkan ekonomi kerakyatan di Indonesia. Jurnal Riset Bisnis Dan Manajemen, 8(1), 15-32. https://ojs.unikom.ac.id/index.php/jurisma/article/view/995

Karsimin, K. (2021). Pengaruh implementasi SAK ETAP dan SOP keuangan terhadap mutu laporan keuangan UKM binaan dinas koperasi dan UMKM di Kota Depok. Cerdika: Jurnal Ilmiah Indonesia, 1(2), 120-137. https://doi.org/10.36418/cerdika.v1i2.20

Kementerian Koperasi dan Usaha Kecil dan Menengah. (2020). Peraturan Menteri Koperasi Dan Usaha Kecil Dan MenengahNomor 5 Tahun 2020 tentang Rencana Strategis Kementerian Koperasi dan UKM Tahun 2020-2024 (p. 13). Kementerian Koperasi dan Usaha Kecil dan Menengah.

Kieso, D. E., Weygandt, J. J., \& Warfield, T. D. (2018). Intermediate Accounting: IFRS Edition, 3rd Edition. John Wiley \& Sons, Inc. https://www.google.co.id/books/edition/Intermediate_Accounting/VXH5twEACAAJ?hl $=$ en

Kurniawan, A., \& Firmansyah, A. (2021). Implementation of PSAK 71 In Indonesia mutual fund investment in insurance subsector companies. Jambura Equilibrium Journal, 3(2), 94-111. https://doi.org/10.37479/jej.v3i2.11136

Laliwu, J., Sumual, T. E. M., \& Tanor, L. A. O. (2021). Analisis penyajian laporan keuangan koperasi simpan pinjam global mandiri berdasarkan PSAK ETAP Desa Beo Kabupaten Talaud. Jurnal Akuntansi Manado (JAIM), 1(1), 105-117. https://doi.org/10.53682/jaim.v2i1.529

Menteri Koperasi dan Usaha Kecil dan Menengah. (2015). Peraturan Menteri Koperasi dan UKM RI Nomor 13 Tahun 2015 tentang Pedoman Akuntansi Simpan Pinjam Oleh Koperasi. Menteri Koperasi dan Usaha Kecil dan Menengah. https://kemenkopukm.go.id/uploads/laporan/1569826353_Permenkop Nomor 13 tahun 2015 tt pedoman akuntansi usaha simpan pinjam oleh koperasi .pdf 


\section{JURNALKU}

Volume 1 No. 4, Desember 2021

Republik Indonesia. (1992). Undang-Undang Nomor 25 Tahun 1992 Tentang Perkoperasian. Republik Indonesia.

Rizaty, M. A. (2021). Daftar Provinsi dengan Jumlah SHU Koperasi Terbesar di 2020. https://databoks.katadata.co.id/datapublish/2021/06/17/tertinggi-nasional-shu-koperasidi-jawa-timur-mencapai-rp132-triliun-pada-2020

Saing, H. J., \& Firmansyah, A. (2021). The impact of PSAK 73 implementation on leases in Indonesia telecommunication companies. International Journal of Economics, Business and Accounting Research (IJEBAR), 5(3), 1033-1049. http://jurnal.stieaas.ac.id/index.php/IJEBAR/article/view/2804

Siagian, R. P., \& Pangemanan, S. S. (2016). Analisis Penyajian Laporan Keuangan Berdasarkan Penerapan. Jurnal EMBA: Jurnal Riset Ekonomi, Manajemen, Bisnis Dan Akuntansi, 4(1), 1450-1460. https://doi.org/10.35794/emba.4.1.2016.12365

Simatupang, E. M. (2018). Analisis penyajian laporan keuangan berdasarkan SAK-ETAP pada kopdit $\mathrm{Cu}$. Karya Nyata Pematang Siantar. Jurnal Akuntansi Barelang, 2(2), 53-63.

Tama, S. B., \& Firmansyah, A. (2021). Perbedaan perlakuan pendapatan dari kontrak dengan pelanggan sebelum dan sesudah penerapan PSAK 72 di Indonesia. Bilancia: Jurnal Ilmiah Akuntansi, $5(3)$ 270-280. https://www.ejournal.pelitaindonesia.ac.id/ojs32/index.php/BILANCIA/article/view/139 2

Yuniarsih, N. (2016). Analisis kepatuhan laporan keuangan koperasi berdasarkan SAK ETAP. Jurnal Bisnis Perspektif, 8(1), 9-18. https://doi.org/10.37477/bip.v8i1.32 